\title{
SATGAS GOTONG ROYONG PENCEGAHAN COVID 19 BERBASIS DESA ADAT SEBAGAI UPAYA PEMERINTAH PROVINSI BALI MEMUTUS RANTAI PENYEBARAN VIRUS COVID-19 Oleh:
}

I Gusti Ayu Jatiana Manik Wedanti ${ }^{1}$

E-mail: ayu.wedanti@gmail.com ${ }^{1}$

Dosen Hukum, Universitas Hindu Negeri I Gusti Bagus Sugriwa Denpasar

\begin{abstract}
The establishment of the Satgas Gotong Royong Pencegahan Covid-19 or Covid-19 Mutual Assistance Officer Unit is a policy taken by the Governor of Bali Province in responding to the rate of spread of COVID-19 in the Bali Province area. This strategic step is a form of harmonization between the Government and its people in preventing the spread of COVID-19. Prevention through this Task Force is an Indigenous Village-based prevention which is seen as effective in preventing the spread of COVID-19 in the Bali Province area and there is a pararem that strengthens the Task Force in carrying out its duties. Using normative research and qualitative descriptive analysis, it can be concluded that the Task Force for Covid-19 Prevention is an implementation of the harmonization of the Bali Provincial Government with the Balinese customary law community in this case the Traditional Village to jointly prevent and break the chain of the spread of COVID-19.
\end{abstract}

Keywords: Covid-19, Desa Adat, Harmonization, Pararem, Government, Task Force.

\section{Abstrak}

Pembentukan Satgas Gotong Royong Pencegahan Covid-19 merupakan kebijakan yang diambil oleh Gubernur Provinsi Bali dalam menyikapi laju penyebaran covid-19 di wilayah Provinsi Bali. Langkah strategis ini merupakan bentuk harmonisasi antara Pemerintah dengan masyarakatnya dalam melakukan pencegahan penyebaran covid-19. Pencegahan melalui Satgas ini merupakan pencegahan berbasis Desa Adat yang mana hal ini dilihat efektif dalam mencegah penyebaran covid-19 di wilayah Provinsi Bali dan adanya pararem yang memperkuat Satgas dalam melakukan tugasnya. Menggunakan penelitian normatif dan analisis deskriptif kualitatif maka dapat disimpulkan bahwa Satgas Gotong Royong Pencegahan Covid-19 ini merupakan implementasi harmonisasi Pemerintah Provinsi Bali dengan masyarakat hukum adat Bali dalam hal ini Desa Adat untuk bersamasama melakukan pencegahan sekaligus memutus mata rantai penyebaran covid-19.

Kata Kunci : Covid-19, Desa Adat, Harmonisasi, Pararem, Pemerintah, Satgas.

\section{PENDAHULUAN}

Penanggulangan penyebaran
virus covid-19 sudah dilakukan Pemerintah dengan baik dalam berbagai bentuk dan upaya guna memutus rantai penyebaran virus covid-19 di Indonesia. Pemerintah pun sudah mengeluarkan berbagai macam regulasi hukum sebagai landasan dalam melakukan penanggulangan penyebaran virus covid-19. Covid-19 merupakan penyakit yang disebabkan oleh SARS-COV2 yang termasuk dalam keluarga besar coronavirus yang sama dengan penyebab SARS pada tahun 2003 , hanya berbeda jenis virusnya. Gejalanya mirip dengan SARS, namun angka kematian SARS $(9,6 \%)$ lebih tinggi dibanding Covid-19 (saat ini kurang dari 5\%), walaupun jumlah kasus Covid-19 jauh lebih banyak dibanding SARS. Covid-19 
SATGAS Gotong Royong Pencegahan Covid 19 Berbasis Desa Adat Sebagai Upaya Pemerintah Provinsi Bali Memutus Rantai Penyebaran Virus Covid-19 (Jatiana Manik Wedanti., 115-125)

juga memiliki penyebaran yang lebih luas dan cepat ke beberapa negara dibanding SARS (Safrizal ZA, dkk., 2020, hal.2-3). Covid-19 dapat mengakibatkan gejala yang ringan atau sedang, seperti demam dan batuk, dan kebanyakan bisa sembuh dalam beberapa minggu. Tapi bagi sebagian orang yang berisiko tinggi (kelompok lanjut usia dan orang dengan masalah kesehatan menahun, seperti penyakit jantung, tekanan darah tinggi, atau diabetes), covid-19 dapat menyebabkan masalah kesehatan yang serius bagi penderitanya. Dengan kecepatan penyebarannya yang tidak dapat dipastikan dan penyebaran covid-19 bersifat masif serta global maka World Health Organization (disingkat WHO) menetapkan kondisi sebagai pandemi Covid-19 pertanggal 9 Maret 2020 lalu. Setelah pandemi covid-19 ditetapkan, Pemerintah Indonesia benar-benar berupaya keras untuk mengantisipasi sekaligus menanggulangi penyebaran virus covid-19 di Indonesia. Hal tersebut dapat dilihat dalam berbagai bentuk kebijakan yang dikeluarkan oleh Pemerintah sebagai landasan antisipasi dan pencegahan penyebaran virus Covid-19.

Bentuk-bentuk upaya pencegahan tersebut di awali dengan diterapkannya pembatasan sosial berskala besar sebagaimana diatur dalam Pasal 1 Peraturan Pemerintah Nomor 21 Tahun 2020 tentang Pembatasan Sosial Berskala Besar Dalam Rangka Percepatan Penanganan Corona Virus Disease 2019 (Covid-19) merupakan pembatasan kegiatan tertentu penduduk dalam suatu wilayah yang diduga terinfeksi Corona Virus Disease 2019 (Covid-19) sedemikian rupa untuk mencegah kemungkinan penyebaran Corona Virus Disease 2019 (Covid-19). Dengan keluarnya peraturan pemerintah tersebut yang kemudian menjadi cikal bakal bentukbentuk pembatasan yang diharapkan dapat menekan laju penyebaran covid19 di masyarakat. Pemerintah Provinsi Bali pun tidak tinggal diam mengingat dampak yang timbul dari pandemi covid-19 ini sangat luas terutama dalam sektor pariwisata yang merupakan sektor utama penghidupan masyarakat Bali. Gubernur Bali pun mengambil upaya untuk memutus penyebaran Virus Covid-19 dengan membuat kebijakan atau diskresi. Diskresi adalah pertimbangan sendiri, wewenang untuk melaksanakan kebijakan sendiri, pertimbangan seorang pejabat publik untuk melaksanakan tugasnya, dan kekuasaan seseorang untuk mengambil pilihan melakukan atau tidak melakukan (Adli dan Ali Yusri, 2020, hal. 72). Ketentuan Pasal 1 angka 9 Undang-Undang No. 30 Tahun 2014 tentang Administrasi Pemerintahan menentukan Diskresi adalah keputusan dan/atau tindakan yang ditetapkan dan/atau dilakukan oleh Pejabat Pemerintahan untuk mengatasi persoalan konkret yang dihadapi dalam penyelenggaraan pemerintahan dalam hal peraturan perundang-undangan yang memberikan pilihan, tidak mengatur, tidak lengkap atau tidak jelas, dan/atau adanya stagnasi pemerintahan. diskresi merupakan salah satu hak pejabat administrasi negara dalam menjalankan tugas, tetapi pelaksanaan tugas melalui diskresi tersebut hanya dapat dilakukan oleh pejabat yang berwenang. Keputusan atau tindakan pejabat secara bahasa dapat didefinisikan dua hal yang berbeda namun memiliki tujuan yang sama. Keputusan berkaitan dengan tindakan yang dilakukan melalui kebijakan berupa penetapan sedangkan tindakan dapat diartikan sebagai perlakuan secara langsung oleh pejabat tanpa melalui penetapan. Melibatkan Masyarakat Hukum adat Bali sebagaimana disebut sebagai Desa Adat sesuai dengan 
ketentuan Pasal 1 angka 8 Perda Provinsi Bali Nomor 4 Tahun 2019 Tentang Desa Adat (selanjutnya disebut Perda Bali 4/2019) merupakan upaya efektif dalam menekan laju penyebaran virus covid-19 di masyarakat. Desa adat merupakan masyarakat hukum adat Bali itu sendiri sehingga dengan melibatkan Desa Adat maka secara tidak langsung melibatkan masyarakat itu sendiri dalam pencegahan virus Covid-19 menyebar lebih luas dan membuat masyarakat sadar akan pentingnnya protokol kesehatan pencegahan Covid-19. Mempertimbangkan bahwa semakin meningkatnya pasien covid19 di semua wilayah kabupaten/kota Provinsi Bali dan Desa adat memiliki peranan strategis dalam pencegahan penyebaran virus covid-19 maka Gubernur Bali mengambil kebijakan dengan mengeluarkan Keputusan Bersama Gubernur Bali dan Majelis Desa Adat Provinsi Bali Nomor: 472/1571/PPDA/DPMA; Nomor: 05/SK/MDA-Prov Bali/III/2020 tentang Pembentukan Satuan Tugas Gotong Royong Pencegahan Covid-19 Berbasis Desa Adat di Bali (selanjutnya disingkat Kepber Satgas Covid-19)

(https://jdih.baliprov.go.id/: $\quad$ diakses pada tanggal 5 Juli 2021).

Tujuan utama dikeluarkannya Kepber Satgas Covid-19 tersebut diatas merupakan diskresi Gubernur Bali untuk mempercepat pembentukan Satgas Covid-19 yang melibatkan Desa adat di dalamnya. Di samping itu hal tersebut juga menunjukkan bahwa eksistensi Desa Adat dalam pemerintahan sangat diperlukan khususnya dalam keadaan darurat karena pandemi covid-19 seperti saat ini. Sebagaimana tujuan dari diskresi kebijakan yang memiliki tujuan utama pembentukannya ialah untuk memberikan arahan ( petunjuk, pedoman) kepada pejabat bawahan agar lancar dalam melaksanakan fungsi dan tugasnya. Selain itu juga ditujukan mengisi kekosongan aturanaturan hukum dalam keadaan yang mendesak dan bersifat darurat, atau setidaknya untuk melengkapi menyempurnakan ketentuan yang tidak sesuai lagi dengan tuntutan kebutuhan akan penyelenggaraan pemerintahan yang baik dan sesuai pula dengan sisi kepentingan dan kebutuhan masyarakat (Adli dan Ali Yusri, 2020, hal.73). Dihubungkan dengan pembentukan Satgas Covid19 ini maka Kepber memperkuat eksistensi Desa Adat untuk ikut serta melakukan upaya pencegahan dan penanggulangan penyebaran Covid-19 sekaligus bentuk pelaksanaan kewajiban Desa Adat untuk menjaga kasukertan (kedamaian) wilayahnya.

Adanya Kepber Satgas Gotong Royong Covid-19 menunjukkan bahwa Pemerintah memang serius dalam penanganan penyebaran covid-19 dengan melibatkan Desa Adat sebagai salah satu garda terdepan dalam mencegah penyebaran covid-19 dalam lingkup wilayah Desa Adat. Apakah dengan dikeluarkannya Kepber Satgas Covid-19 merupakan bentuk harmonisasi antara Pemerintah dengan Desa Adat dalam mencegah penyebaran covid-19 dan bagaimana prosedur pembentukan Satgas Gotong Royong Covid-19 sesuai dengan pengaturan yang ada. Dalam tulisan ini, penulis akan menganalisis permasalahan tersebut sehingga dapat memberikan simpulan sesuai dengan permasalahan dalam tulisan ini.

\section{METODE}

Menggunakan metode penelitian hukum normatif dengan mengkaji landasan yuridis keterlibatan Desa Adat dalam upaya pencegahan penyebaran virus covid-19 dan analisis yang bersifat deskriptif kualitatif. Bahan-bahan yang digunakan dalam penelitian ini adalah peraturan 
SATGAS Gotong Royong Pencegahan Covid 19 Berbasis Desa Adat Sebagai Upaya Pemerintah Provinsi Bali Memutus Rantai Penyebaran Virus Covid-19 (Jatiana Manik Wedanti., 115-125)

perundang-undangan yang terkait, literatur hukum, artikel jurnal ilmiah hukum yang relevan serta terupdate dan melakukan observasi melalui berita-berita resmi yang terkait dengan permasalahan penelitian.

\section{PEMBAHASAN}

1. Eksistensi Desa Adat sebagai Kesatuan Masyarakat Hukum Adat Bali

Masyarakat dalam pengertian sehari-hari diartikan sebagai "pergaulan hidup" dan yang lebih tepat lagi masyarakat itu diartikan sebagai kelompok manusia yang hidup bersama dan kehidupan bersama itu merupakan pergaulan hidup. Dalam pergaulan hidupnya itu terdapat polapola perilaku yang dimengerti maknanya oleh setiap warga kelompok. Mereka merasa sebagai satu kesatuan. Masyarakat Hukum, diartikan sebagai suatu kelompok manusia yang hidup bersama dalam tata hukum yang sama (Rechtsgemeenschap) sehingga mereka juga merupakan satu kesatuan. Ciri lainnya adalah bahwa masyarakat hukum mempunyai wewenang hukum (otoritas hukum, Rechtsgezag) dan upaya pemaksa hukum ((Rechtsdwang). Di samping itu juga mempunyai kekayaan dan dapat mengadakan hubungan-hubungan hukum dalam lalu lintas hukum seperti subyek hukum lainnya.

Masyarakat hukum adat adalah sekelompok paguyuban sosial manusia yang bersatu karena terikat oleh kesamaan leluhur dan/atau wilayah tertentu, memiliki kekayaan sendiri, dipimpin oleh seorang atau beberapa orang yang dipandang memiliki kewibawaan atau kekuasaan, memiliki hukumnya sendiri yang dijadikan sebagai pedoman dalam menjalani kehidupan sehari-hari, serta tidak mempunyai keinginan untuk memisahkan diri selama masih memiliki kesamaan pandangan
(Dominikus Rato, 2011, hal.82). Mencermati pengertian mengenai masyarakat hukum adat, terdapat lima unsur yang membentuk masyarakat hukum adat yaitu (Rosdalina, 2017, hal. 113) :

a. Sekelompok manusia yang bersatu, terikat oleh perasaan kebersamaan karena kesamaan keturunan (geneologis) dan/atau wilayah (territorial);

b. Mendiami dan memiliki wilayah tertentu dengan batas-batas wilayah tertentu menurut hukum adat mereka;

c. Memiliki kekayaan sendiri baik berupa kekayaan materiel maupun immaterial;

d. Dipimpin oleh seseorang atau beberapa orang yang memiliki kewibawaan dan kekuasaan yang didukung oleh kelompoknya sebagai perwakilan kelompok.

e. Memiliki hukumnya sendiri sebagai pedoman dalam kehidupan bermasyarakat.

Eksistensi masyarakat hukum adat diakui keberadaannya dalam sistem hukum nasional karena diakui dalam Undang-undang Dasar yang secara hirarkis merupakan peraturan peundang-undangan yang paling tinggi tingkatannya. Pasal 18B ayat (2) UUD NRI Tahun 1945 menentukan bahwa, "Negara mengakui dan menghormati kesatuan-kesatuan masyarakat hukum adat beserta hak-hak tradisionalnya sepanjang masih hidup dan sesuai dengan perkembangan masyarakat dan prinsip Negara Kesatuan Republik Indonesia yang diatur dalam undangundang". Pengakuan negara terhadap eksitensi kesatuan masyarakat hukum adat dan hak tradisionalnya ini sekaligus mengakui eksistensi hukum adat, sebab tanpa adanya normanorma hukum adat, maka suatu kesatuan masyarakat hukum adat tidak dapat lagi diakui keberadaannya. Dengan begitu, hukum adat mempunyai tempat tersendiri dalam 
sistem hukum nasional berdampingan dengan hukum negara. Namun demikian, berdasarkan Pasal 18B ayat (2) UUD NRI Tahun 1945 kedudukan hukum adat lebih lemah dari hukum negara, sebab pengakuan terhadap hukum adat disertai dengan syaratsyarat tertentu, yaitu (1) hukum adat itu masih hidup; (2) hukum adat itu sesuai dengan perkembangan masyarakat; (3) hukum adat itu sesuai dengan prinsip negara kesatuan Republik Indonesia; dan (4) diatur dalam undang-undang. Dengan penafsiran acontrario dapat dikatakan bahwa apabila syarat-syarat tersebut tidak dipenuhi maka hukum adat tidak diakui eksistensinya.

Berdasarkan Pasal 18B ayat (2) ini, sesungguhnya negara juga mengakui hak otonomi dari kesatuan masyarakat hukum adat. Hak otonomi masyarakat hukum adat tersebut yaitu hak membentuk hukumnya sendiri; hak melaksanakan pemerintahan sendiri dalam kerangka Negara Kesatuan RI; hak menjaga keamanannya sendiri dan hak melakukan peradilan sendiri. Oleh karena hak otonomi masyarakat hukum adat sudah diakui oleh negara melalui konstitusinya maka masyarakat hukum adat Bali pun dapat menjalankan otonominya sendiri namun tidak boleh bertentangan dengan negara dan Pancasila.

Bentuk nyata pengakuan dan penerapan otonomi kesatuan masyarakat hukum adat Bali dibuktikan dengan dikeluarkannya peraturan daerah oleh Gubernur Bali yang telah mengalami beberapa kali perubahan. Berawal dari pengaturan kesatuan masyarakat hukum adat Bali disebut sebagai Desa Adat dalam Pasal 1 huruf e, Peraturan Daerah Provinsi Tingkat I Bali Nomor 6 Tahun 1986 tentang Kedudukan, Fungsi dan Peranan Desa Adat Sebagai Kesatuan Masyarakat Hukum Adat dalam Propinsi Daerah Tingkat I Bali menentukan bahwa, "Desa adat sebagai desa dresta adalah kesatuan masyarakat hukum adat di Propinsi Tingkat I Bali yang memiliki satu kesatuan tradisi dan tata krama pergaulan hidup masyarakat Umat Hindu secara turun temurun dalam ikatan Kahyangan Tiga (Kahyangan Desa) yang mempunyai wilayah tertentu dan harta kekayaan sendiri serta berhak mengurus rumah tangganya sendiri". Kemudian beberapa tahun kemudian, diganti dengan Peraturan Daerah Provinsi Bali Nomor 3 Tahun 2001 tentang Desa Pakraman (selanjutnya disebut Perda Bali 3/2001) sebagaimana ditentukan dalam Pasal 1 angka 4 bahwa, "Desa Pakraman adalah kesatuan masyarakat hukum adat di Propinsi Bali yang mempunyai satu kesatuan tradisi dan tata krama pergaulan hidup masyarakat umat Hindu secara turun temurun dalam ikatan Kahyangan tiga atau Kahyangan Desa yang mempunyai wilayah tertentu dan harta kekayaan sendiri serta berhak mengurus rumah tangganya sendiri." Pada tahun 2019 silam, Perda Bali diperbarui dan diganti kembali menjadi Peraturan Daerah Provinsi Bali Nomor 4 Tahun 2019 tentang Desa Adat dalam Pasal 1 Angka 8 menentukan bahwa, "Desa Adat adalah kesatuan masyarakat hukum adat di Bali yang memiliki wilayah, kedudukan, susunan asli, hak-hak tradisional, harta kekayaan sendiri, tradisi, tata krama pergaulan hidup masyarakat secara turun temurun dalam ikatan tempat suci (kahyangan tiga atau kahyanga desa) tugas dan kewenangan serta hak mengatur dan mengurus rumah tangganya sendiri."

Secara de jure dan de facto, kesatuan masyarakat hukum adat Bali yang sekarang disebut sebagai desa adat dapat menggunakan otonomi asli yang dimilikinya asalkan tidak bertentangan dengan negara, UUD 
SATGAS Gotong Royong Pencegahan Covid 19 Berbasis Desa Adat Sebagai Upaya Pemerintah Provinsi Bali Memutus Rantai Penyebaran Virus Covid-19 (Jatiana Manik Wedanti., 115-125)

NRI 1945 dan Pancasila. Dari otonomi tersebut, Desa Adat mempunyai hak membentuk hukumnya sendiri yang disebut sebagai awig-awig; mempunyai hak menyelenggarakan pemerintahan adat sendiri yang dilakukan oleh kepala adat yang disebut sebagai prajuru; mempunyai hak menjaga keamanan wilayahnya sendiri yang dilakukan oleh petugas keamanan tradisional yang disebut sebagai pecalang; dan mempunyai hak melaksanakan sistem peradilan adat untuk menyelesaikan persoalanpersoalan hukum yang terjadi di wilayahnya menyangkut adat dan agama yang disebut sebagai kerta desa (I Ketut Sudantra, Ni Nyoman Sukerti, dan A.A. Istri Ari Atu Dewi, 2015, hal.18). Dalam pelaksanaan hak-haknya itu, desa adat melakukannya secara mandiri tanpa campur tangan kekuasaan negara, namun tetap tidak boleh melanggar rambu-rambu yang ditentukan oleh Negara dalam berbagai peraturan perundang-undangan yang berlaku.

2. Harmonisasi Dalam Pencegahan dan Penanggulangan Penyebaran Covid-19

Penetapan Perda Bali 4/2019 berdasarkan pada pertimbangan bahwa Perda Bali 3/2001 dinilai sudah tidak lagi sesuai dengan perkembangan dan kebutuhan hukum saat ini sehingga perlu adanya pembaharuan dan diganti ke Perda yang lebih bisa mengakomodir perkembangan tersebut. Terdapat tiga dasar pertimbangan pembentukan Perda Bali 4/2019 yaitu pertimbangan filosofis, sosiologis dan yuridis. Secara filosofis, Desa Adat sebagai kesatuan masyarakat hukum adat Bali mendasarkan diri pada filosofi Tri Hita Karana yang berakar dari kearifan lokal yaitu Sad Kerthi, dijiwai oleh ajaran Agama Hindu dan nilai-nilai budaya yang memang sudah ada di dalam masyarakat serta kearifan lokal maka Desa Adat memiliki peranan yang sangat besar dalam pembangunan masyarakat, bangsa dan negara sehingga perlu untuk diayomi, dilindungi, dibina, dikembangkan dan diberdayakan guna mewujudkan kehidupan krama Bali yang berdaulat secara politik dan berdikari secara ekonomi (Gede Marhaendra Wija Atmaja dan Anak Agung Istri Atu Dewi, 2020, hal 200201).

Secara

Sosiologis, perkembangan Desa Adat yang bersifat dinamis dan fleksibel, memiliki hak asal-usul, hak tradisional, dan hak otonomi asli yang melekat di Desa Adat telah memberikan kontribusi besar terhadap keberlangsungan kehidupan masyarakat dalam berbangsa dan bernegara. Secara yuridis, Perda Bali 3/2001 tentang Desa Pakraman dinilai sudah tidak sesuai lagi dengan perkembangan hukum dan kondisi saat ini sehingga perlu pembaharuan dan diganti. Lebih tepatnya dalam rangka memberikan landasan, arah dan kepastian hukum bagi aparatur pemerintah daerah dan pemangku kepentingan dalam mengakui dan menghormati eksistensi Desa Adat (Gede Marhaendra Wija Atmaja dan Anak Agung Istri Atu Dewi, 2020, hal 200-201).

Kejelasan status Desa Adat dapat dilihat dalam Pasal 3 ayat (1) huruf b Perda Bali 4/2019 yang menentukan, "pengaturan Desa Adat bertujuan: b. memberikan kejelasan status dan kepastian hukum atas Desa Adat dalam sistem ketatanegaraan Republik Indonesia demi mewujudkan keadilan bagi seluruh rakyat Indonesia". Dipertegas lagi dalam Pasal 5 Perda Bali 4/2019 menentukan bahwa, "Desa Adat berstatus sebagai subyek hukum dalam sistem pemerintahan Provinsi Bali". Dimaksud sebagai "subyek hukum" menurut penjelasan Pasal 5 Perda Bali 4/2019 yaitu Yang dimaksud Desa Adat sebagai "subyek 
hukum" adalah Desa Adat memiliki hak dan kewajiban yang sama seperti halnya subyek hukum lainnya dan dapat bertindak sendiri baik di dalam maupun di luar pengadilan. Yang dimaksud dalam sistem pemerintahan Provinsi adalah unsur penyelenggaraan urusan pemerintahan Provinsi yang terkait dengan bidang adat, tradisi, budaya, sosial religius, dan kearifan lokal.

Merujuk pada pengertian sistem politik, secara teoritik, ada dua macam struktur yaitu supra struktur pemerintah yakni kelembagaan pemerintahan dan infra struktur politik menyangkut masyarakat dan Desa Adat berada dalam infra struktur atau dalam ranah masyarakat sehingga Desa Adat bukan bagian struktur pemerintahan Provinsi Bali namun terdapat relasi pengakuan Desa Adat sebagai kesatuan masyarakat hukum adat oleh pemerintahan Provinsi Bali dan tidak menunjukkan relasi seperti atasan-bawahan (Gede Marhaendra Wija Atmaja dan Anak Agung Istri Atu Dewi, 2020, hal 200-201). Desa Adat juga memiliki tugas untuk mewujudkan kasukretan Desa Adat yang meliputi ketentraman, kesejahteraan, kebahagiaan dan kedamaian sekala dan niskala (Pasal 21 Perda Bali 4/2019). Terkait dengan pelibatan Desa Adat sebagai Satgas Covid-19 maka Desa Adat sedang melaksanakan tugasnya sebagaimana dalam Pasal 22 huruf 0 yaitu menentukan, "tugas Desa Adat dalam mewujudkan kasukretan sakala dan niskala sebagaimana dimaksud dalam Pasal 21,meliputi:... o. melaksanakan tugas lain yang diserahkan oleh Pemerintah dan Pemerintah Daerah". Dapat dikatakan bahwa pelibatan Desa Adat sebagai Satgas Covid-19 oleh Gubernur Bali merupakan salah satu tugas Desa Adat dalam menjaga kasukretan wilayah Desa Adat utamanya dari ancaman covid-19 agar jangan sampai krama Bali banyak yang menjadi korban covid-19 ini.

Melihat uraian di atas maka sudah sangat jelas bahwa pelibatan Desa Adat sebagai Satgas Gotong Royong Pencegahan Covid-19 merupakan bentuk pelaksanaan tugas Desa Adat dalam menjaga kasukretan Desa Adat dan Kepber Satgas Gotong Royong Covid-19 merupakan legitimasi kedudukan Desa Adat sebagai Satgas Gotong Royong Covid-19. Tugas Satgas Gotong Royong sebagaimana ditentukan dalam Kepber Satgas Covid-19 pun merujuk pada tugas Desa Adat sebagaimana dalam Pasal 22 Perda Bali 4/2019. Dapat diuraikan secara garis besar tugas Satgas Gotong Royong Covid-19 antara lain:

a. Tugas utama adalah memberdayakan Krama Desa Adat dan Pemuda-Pemudi Desa Adat untuk ikut bergotong royong dalam mencegah penyebaran covid-19 di wilayahnya dengan menggunakan fasilitas Desa Adat dan berkoordinasi dengan pihak-pihak terkait;

b. Tugas secara niskala adalah melakukan persembahyangan bersama dan memohon kepada Tuhan Yang Maha Esa di masingmasing Pura Kahyangan Tiga Desa Adat agar pandemi covid-19 ini segera berakhir demi keharmonisan alam, krama dan Budaya Bali;

c. Tugas secara sekala antara lain melakukan pencegahan Covid-19 dan membangung gotong royong sesama Krama Desa Adat.

Pembentukan Satgas Gotong Royong dilakukan oleh krama Desa Adat dipimpin oleh prajuru desa yaitu Bendesa Adat atau Kelihan Adat dan Kepala Desa atau Lurah setempat secara musyawarah mufakat. Dalam musyawarah atau paruman yang maka dilakukan perumusan sebuah pararem atau aturan yang didasari pada fakta yang terjadi di masyarakat yaitu 
SATGAS Gotong Royong Pencegahan Covid 19 Berbasis Desa Adat Sebagai Upaya Pemerintah Provinsi Bali Memutus Rantai Penyebaran Virus Covid-19 (Jatiana Manik Wedanti., 115-125)

dampak meluasnya penyebaran Covid-19 di masing-masing wilayah desa adat. Hasil paruman yang dilakukan oleh prajuru desa adat terkait dengan tugasnya sebagai Satgas Gotong Royong Covid-19 dan dengan melihat penyebaran yang semakin meluas, maka umumnya pelaksanaan tugas dilakukan dengan ketentuan-ketentuan sebagai berikut:

a. Melakukan pengecekan terhadap warga luar desa yang memasuki wewidangan atau wilayah Desa Adat;

b. Penduduk pendatang, khususnya pendatang yang tinggal sementara, tidak di perbolehkan untuk membawa tamu dari luar wilayah desa adat;

c. Penduduk pendatang yang tinggal sementara seperti menyewa tempat tinggal di wilayah desa adat, di perbolehkan untuk kembali ke tempat asalnya, namun apabila kondisi dan situasi desa adat masih dalam status zona merah maka mereka tidak diijinkan untuk memasuki wilayah desa adat;

d. Pecalang selaku polisi adat melakukan penjagaan di pos desa adat yang sudah di tentukan;

e. Membuat pos jaga sesuai dengan titik lokasi yang telah ditentukan dengan pertimbangan keamanan dan strategis dalam melakukan pengawasan;

f. Melakukan penyemprotan disinfectan secara rutin di tempattempat umum, mulai dari sekolahsekolah, balai banjar, pura, perkantoran, serta pasar yang setiap pagi ada aktifitas yang dilakukan oleh masyarakat, selain melakukan penyemprotan di wewidangan desa adat, desa adat juga membagikan masker secara gratis kepada krama/warga desa adat (I Wayan Eka Artajaya dan I Wayan Wiasta, 2020, hal.52).

Pararem merupakan salah satu landasan yuridis yang digunakan oleh krama desa dalam menjalankan tugasnya sebagai Satgas. Pararem merupakan hasil keputusan bersama mengenai hal-hal yang bersifat khusus dalam sebuah paruman atau rapat musyawarah adat di Desa Adat serta belum diatur dalam awig-awig yang kemudian disepakati bersama untuk menjadi sebuah aturan hukum adat. Pada umumya pararem berisi ketentuan-ketentuan serta sanksi lanjutan dari awig-awig yang dirasa belum ada, namun tidak menutup kemungkinan pararem juga bisa dibuat untuk hal-hal tertentu yang belum dimuat dalam awig-awig (Sukawati Lanang P Perbawa, 2020, hal. 28). Dilihat dari substansinya, pararem dapat digolongkan dalam tiga golongan yaitu:

1) Pararem penyahcah awig, yaitu keputusan-keputusan paruman yang merupakan aturan pelaksanaan dari awig-awig;

2) Pararem ngele/ pareram lepas, yaitu keputusan paruman yang merupakan aturan hukum baru yang tidak ada landasannya dalam awigawig tetapi dibuat untuk memenuhi kebutuhan hukum masyarakat;

3) Pararem penepas wicara, yang berupa keputusan Paruman mengenai suatu persoalan hukum (perkara) tertentu, baik yang berupa sengketa maupun pelanggaran hukum (pararem panepas wicara) (I Ketut Sudantra dan I Wayan P. Windia, 2011, hal. 11).

Guna membuat masyarakat patuh, dalam penerapannya apabila ada yang melanggar awig-awig maupun pararem akan dikenakan sanksi adat. Sanksi adat tersebut dikenal dengan istilah pamidanda, mempunyai tujuan untuk mengembalikan keseimbangan bila terjadi gangguan keseimbangan hubungan dalam aspek-aspek kewilayahan (palemahan), kemasyarakatan (pawongan), dan keagamaan (parhyangan). 
Seluruh desa adat di Bali yang berjumlah 1.493 tercatat telah memiliki pararem tentang Pengaturan Pencegahan dan Pengendalian Gering Agung. Pembuatan pararem untuk masing-masing wilayah desa adat ini merupakan tindak lanjut dari Instruksi Gubernur Bali Wayan Koster yang bertujuan guna mempercepat penanggulangan pandemi Covid-19 di Provinsi Bali sekaligus digunakan sebagai dasar dalam bertugas bagi Satgas Gotong Royong covid-19 (https://www.baliprov.go.id/web/1-493desa- adat-di-bali-miliki-pararempencegahan-gering-agung/ : diakses pada tanggal 10 Juli 2021). Melihat dari jenis pararem maka pararem tentang Pengaturan Pencegahan Dan Pengendalian gering agung ini merupakan pararem ngele atau pararem lepas karena pararem ini di buat untuk memenuhi kebutuhan hukum krama desa dalam menjalankan tugasnya sebagai Satgas sekaligus melakukan pencegahan dan penanggulangan penyebaran covid-19 di wilayah desa adat masing-masing. Di samping itu juga, adanya pararem ini merupakan bentuk tindak lanjut Desa Adat untuk mengikuti instruksi Gubernur Bali yang bertujuan untuk mempercepat penanggulangan pandemi covid-19. Perihal penegasan kewajiban pembuatan pararem pengendalian gering agung yang dalam hal ini Covid-19, maka diharapkan seluruh desa adat di Bali sudah menindaklanjuti dengan pembentukan pararem di desa adat masing-masing. Dalam Surat Majelis Desa Adat (MDA) Propinsi Bali nomor: 044/MDAProv-Bali/VI/2020 tersebut ada 5 point yang disampaikan, yaitu dari apa saja kewajiban desa adat yang disusun dalam pararem pangele tentang Pengaturan, Pencegahan, dan Pengendalian Gering Agung Covid 19 di Wilayah atau wewidangan Desa Adat, sampai dengan point akhir tentang penyampaian, pengesahan dan pendaftaran pararem dimaksud. Dalam surat itu juga dilampirkan bagaiman cara menyusun dan prosedur menyusun pararem. Dari berbagai pararem desa adat yang sudah dibuat dan ada serta sudah di sahkan, secara garis besar hal-hal berikut ini yang dimuat di dalamnya, yaitu:

1) Ketentuan umum, pengertian tentang desa adat, banjar adat, prajuru desa adat dan perarem;

2) Maksud dan tujuan dibuatnya pararem pararem tentang Gering Agung ini, yaitu dalam rangka pencegahan dan pengendalian Covid-19.

3) Ruang lingkup pencegahan dan pengendalian, meliputi: perilaku hidup sehat, pembatasan kegiatan berbasis desa adat, satuan tugas gotong royong, penanganan kasus terpapar, penyucian wewidangan desa adat secara niskala, sanksi adat atau pamidanda dan ketentuan penutup (Sukawati Lanang $\mathrm{P}$ Perbawa, 2020, hal. 29).

Semua lapisan masyarakat di Provinsi Bali berharap dengan adanya pararem yang diputuskan dapat mencegah dan mengendalikan Covid 19, dan bias menjalakan kehidupan sebagaimana sebelumnya dengan tetap menjalankan protokol kesehatan covid-19.

Keputusan Gubernur Bali untuk melibatkan desa adat dalam pencegahan dan penangulangan covid-19 dalam bentuk Satgas Gotong Royong Pencegahan Covid-19 merupakan langkah tepat, karena eksistensi desa adat sebagai subyek hukum dan merupakan bagian dari sistem pemerintahan provinsi Bali sudah mendapatkan legitimasi dari Perda Bali 4/2019 sehingga Desa Adat berhak atas kewenangan mengatur wilayahnya. Melihat masyarakat hukum adat Bali sangat kuat dalam menjaga kasukretan wilayahnya maka Pemerintah Provinsi Bali dalam 
SATGAS Gotong Royong Pencegahan Covid 19 Berbasis Desa Adat Sebagai Upaya Pemerintah Provinsi Bali Memutus Rantai Penyebaran Virus Covid-19 (Jatiana Manik Wedanti., 115-125)

melaksanakan kebijakan khususnya selama pandemi covid-19 menggunakan desa adat sebagai ujung terdepan dalam pemutus rantai penyebaran covid-19. Satgas Gotong Royong Covid-19 dalam melakukan pencegahan penyebaran covid-19, menggunakan konteks, komposisi, dan proses yang tepat (Made Chandra Mandira dan Cokorda Krisna Yudha, 2021, hal. 16). Konteks dalam hal ini adalah sumber daya manusia Bali yaitu masyarakat hukum adat yang mengutamakan nilai-nilai budaya dan kearifan lokal menjadi poin utama dalam pencegahan penyebaran covid19. Komposisi masyarakat yaitu kemampuan dan fleksibilitas dalam beradaptasi dengan lingkungannya. Dalam situasi pandemi covid-19, masyarakat hukum adat Bali secara cepat dapat beradaptasi dengan lingkungan. Proses dalam hal ini adalah mewujudkan tim yang efektif yaitu dapat melalui potensi konflik, dengan kualitas sumber daya manusia dan kemampuan adaptasi yang baik, tingkat potensi konflik dapat direda sehingga situasi dan kondisi dapat diatur sesuai dengan harapan pemerintah (Made Chandra Mandira dan Cokorda Krisna Yudha, 2021, hal. 16). Maka dari itu, pembentukan Satgas Gotong Royong Pencegahan Covid-19 berbasis Desa Adat ini dinilai paling efektif dalam menekan laju penyebaran virus covid-19 di wilayah Provinsi Bali.

\section{PENUTUP}

Pembentukan Satgas Gotong Royong Pencegahan Covid-19 merupakan langka strategis yang efektif dalam pencegahan penyebaran virus covid-19 di wilayah Provinsi Bali. Langkah pencegahan berbasis Desa Adat ini harus dimaknai sebagai langkah bersama yang tidak hanya melibatkan unsur Pemerintah namun juga peran dari unsur Desa Adat. Sinergitas antara pemerintah dan desa adat dirasa akan lebih efektif dalam menekan laju penyebaran covid-19. Satgas Gotong Royong di dukungng pula dengan dibuatnya pararem tentang pengendalian gering agung juga memperkuat harmonisasi antara Pemerintah dengan Desa Adat. Pararem menjadi pedoman dalam strategi pencegahan penyebaran covid-19 berbasis adat yang tidak hanya menekankan pada aspek pawongan, namun juga parhyangan dan palemahan, sehingga hal ini dapat mendukung pelaksanaan penanggulangan penyebaran virus COVID- 19 baik secara sekala maupun niskala. Oleh karena itu, diharapkan harmonisasi ini tidak berhenti begitu saja namun tetap dilakukan mengingat pandemi covid19 belum dinyatakan berakhir. Desa adat melalui Satgas Gotong Royong Pencegahan Covid-19 diharapkan dapat terus secara konsisten untuk mengatur masyarakat desa setempat baik melalui perangkat keamanan maupun perarem untuk selalu menegakkan protokol kesehatan kepada masyarakat.

\section{DAFTAR PUSTAKA}

Adli dan Ali Yusri. 2020. "Penegakan Hukum Pemerintahan: Kekuasaan Walikota Pekanbaru Memberlakukan Beleidsregels Guna Memutus Penyebaran Virus Covid- 19 Di Kota Pekanbaru". JURNAL ILMIAH MUQODDIMAH: Jurnal IImu Sosial, Politik, dan Humaniora. Volume 4, Nomor 2, Agustus 2020.

Dominikus Rato.2011. Hukum AdatSuatu Pengantar Singkat Memahami Hukum Adat Di Indonesia. LaksBang. Yogyakarta.

Gede Marhaendra Wija Atmaja dan Anak Agung Istri Atu Dewi, Desa Adat Sebagai Kesatuan Masyarakat Hukum Adat di Bali, dalam Wayan P.Windia, DKK. 
2020. Hukum Adat dan Desa Adat Di Bali, Udayana University Press, Denpasar.

I Ketut Sudantra dan I Wayan P. Windia 2011.Penuntun Penyuratan Awig-awig, Udayana University Press. Denpasar.

I Ketut Sudantra, Ni Nyoman Sukerti, dan A.A. Istri Ari Atu Dewi, (2015), "Identifikasi Lingkup Isi dan Batas-batas Otonomi Desa Pakraman dalam Hubungannya dengan Kekuasaan Negara", Jurnal Magister Hukum Udayana, Vol. 4 No. 1 Mei 2015.

I Wayan Eka Artajaya, I Wayan Wiasta. "Desa Adat Menjadi Benteng Terakhir Dalam Memutus Penyebaran Covid-19 Study Pada Desa Adat Tegallalang Gianyar Bali”. Dalam Prosiding Seminar Nasional Webinar Nasional Universitas Mahasaraswati Denpasar, Mahasaraswati Press. 11 November 2020.

Keputusan Bersama Gubernur Bali dan Majelis Desa Adat Provinsi Bali Nomor: 472/1571/PPDA/DPMA; Nomor: 05/SK/MDA-Prov Bali/III/2020 tentang Pembentukan Satuan Tugas Gotong Royong Pencegahan Covid-19 Berbasis Desa Adat di Bali.

Made Chandra Mandira dan Cokorda Krisna Yudha. "Peran Desa Adat Bali Dalam Melancarkan Kebijakan Penanggulangan Pandemi Covid-19". Journal Publicuho. Volume 4 Number 1 (February-April), (2021). DOI: 10.35817/jpu.v4i1.15993.

Peraturan Daerah Provinsi Bali Nomor 3 Tahun 2001 tentang Desa Pakraman.
Peraturan Daerah Provinsi Bali Nomor 4 Tahun 2019 tentang Desa Adat.

Peraturan Daerah Provinsi Tingkat I Bali Nomor 6 Tahun 1986 tentang Kedudukan, Fungsi dan Peranan Desa Adat Sebagai Kesatuan Masyarakat Hukum Adat dalam Propinsi Daerah Tingkat I Bali.

Peraturan Pemerintah Nomor 21 Tahun 2020 tentang Pembatasan Sosial Berskala Besar Dalam Rangka Percepatan Penanganan Corona Virus Disease 2019 (Covid-19).

Rosdalina.2017.Hukum Adat. Deepublish.Yogyakarta.

Safrizal ZA, DKK. 2020. Pedoman Umum Kesiapsiagaan Menghadapi Penyakit Coronavirus (2019-nCoV) untuk Pemerintah Daerah. Tim Penyusun Kementerian Dalam Negeri. Jakarta.

Sukawati Lanang P Perbawa. "Implementasi Kebijakan Pemerintah Melalui Perarem Desa Adat Dalam Penanganan Covid 19". Dalam Prosiding Seminar Nasional Webinar Nasional Universitas Mahasaraswati Denpasar, Mahasaraswati Press. 11 November 2020.

Surat Majelis Desa Adat (MDA) Propinsi Bali nomor: 044/MDAProv-Bali/VI/2020.

Undang-Undang Dasar Negara Republik Indonesia Tahun 1945

Undang-Undang No. 30 Tahun 2014 tentang Administrasi 